\title{
Distribution and Activation of \\ Chitin Synthase in Protoplast Fractions Released during the Lytic Digestion of Aspergillus nidulans Hyphae
}

\author{
By S. ISAAC, N. S. RYDER* AND J. F. PEBERDY \\ Department of Botany, University of Nottingham, Nottingham NG7 2RD
}

(Received 18 July 1977)

\begin{abstract}
Protoplasts were produced from Aspergillus nidulans mycelium using Trichoderma lytic enzyme. The influence of $\mathrm{KCl}$ and $\mathrm{MgSO}_{4}$ as stabilizer systems on the morphological variation of protoplasts produced during digestion and the pattern of release from hyphae were compared. The results suggest that protoplast release in the presence of $\mathrm{KCl}$ followed a sequential fractionation of the hyphae with 'early' protoplasts originating from the tip regions and 'late' protoplasts from the distal regions. In $\mathrm{MgSO}_{4}$-stabilized systems the hyphae were disrupted in a less ordered fashion. Between 12 and $16 \%$ of the mycelial protein was recovered in protoplast form using the systems described.

The level of chitin synthase (EC 2.4.1.16) and the capacity for trypsin-activation of the enzyme in protoplast fractions was investigated. In KCl-stabilized systems, 'early' $(1 \mathrm{~h})$ fractions possessed higher specific activities than later fractions. Activatable enzyme was low in the early fraction but was present at high levels in later fractions. It is suggested that these observations are consistent with a model relating active and activatable enzyme to hyphal growth.
\end{abstract}

\section{INTRODUCTION}

The fungal hypha is characterized by two related features, an almost unique ultrastructural organization and apical growth. In the longitudinal axis the hypha can be divided into distinct apical, sub-apical and distal regions on the basis of organelle distribution (Grove \& Bracker, 1970). The cytochemical observations made by Zalokar (1965) indicate a zonation of biochemical activities. Apical growth of the fungal hypha results from the integration of many functions as proposed in the model of Bartnicki-Garcia (1973). A corollary of this model is the apical and sub-apical location of the synthase enzymes involved in wall synthesis, with the possibility of inactive enzymes in sub-apical and distal zones. The limitation of synthesis of wall polymers to specific sites in the hypha is of current interest in view of the proposed control system for septum synthesis in Saccharomyces cerevisiae (Cabib, 1975). In this connexion there have been several reports demonstrating that proteolytic activation systems associated with chitin synthase may be operative in growing hyphae (Lopez-Romero \& Ruiz-Herrera, 1976; Ruiz-Herrera \& Bartnicki-Garcia, 1976; Ryder \& Peberdy, 1977).

During protoplast isolation the highly integrated structure of the hypha becomes subdivided into discrete heterogeneous units (Villanueva \& Garcia Acha, 1971; Peberdy, 1976). This was first recognized in Phytophthora cinnamomi where variation in protoplast morphology was observed (Bartnicki-Garcia \& Lippman, 1966). Subsequently it was shown that

* Present address: Department of Biochemistry, University of Liverpool. 
protoplasts released in the first hour of a lytic digestion of Aspergillus nidulans mycelium originated from apical regions of the hyphae and those appearing later came from distal regions (Gibson \& Peberdy, 1972). Electron micrographs of these 'early' and 'late' protuplasts showed differences in ultrastructure that could be related to their original hyphal location. This paper describes the influence of osmotic stabilizers on protoplast release from hyphae of Aspergillus nidulans. The distribution and activation of chitin synthase (EC 2.4.1.16) in protoplast fractions was investigated in an attempt to give a biochemical expression to the previous cytological and morphological observations.

\section{METHODS}

Organisms and culture procedures. Aspergillus nidulans strain BDUN33 (formerly University of Nottingham collection NF33), a green-spored prototrophic strain, was maintained on malt extract agar. Similar cultures were used for the preparation of conidial suspensions.

Trichoderma harzianum, cBs 354-33 (kindly supplied by Professor J. G. H. Wessels) was maintained on TLE medium, supplemented with ball-milled chitin and laminaria meal and solidified with agar (Peberdy \& Isaac, 1976).

Lytic enzyme production. Lytic enzyme was prepared from culture filtrates of $T$. harzianum by the method previously described (Peberdy \& Isaac, 1976).

Protoplast isolation. Digestion mixtures were set up as described previously (Peberdy \& Isaac, 1976), using either $0.1 \mathrm{M}$-phosphate buffer $\mathrm{pH} 5.8$ plus $0.6 \mathrm{M}-\mathrm{KCl}$ or $0.01 \mathrm{M}$-phosphate buffer $\mathrm{pH} 5.8$ plus $0.6 \mathrm{M}-\mathrm{MgSO}_{4}$ (final concentration in the digestion mixture), as buffer/stabilizer systems, with an equal volume of Trichoderma lytic enzyme and $0.02 \mathrm{~g}$ fresh weight mycelium ml ${ }^{-1}$. Protoplasts were harvested from these mixtures at 1,2 and $3 \mathrm{~h}$ after the start of digestion, residual mycelium being replaced in the lytic mixture after each harvest. Where $\mathrm{KCl}$ was used as stabilizer, each harvest was made by filtration through sintered-glass filters (porosity 1 ) and protoplasts were collected by centrifuging at $800 \mathrm{~g}$. In experiments using $\mathrm{MgSO}_{4}$ as stabilizer, the $1 \mathrm{~h}$ harvest was made by filtration, but in the two subsequent harvests the protoplasts were recovered by flotation after centrifuging at $800 \mathrm{~g}$ (De Vries \& Wessels, 1975). The flotation process was repeated three times to ensure complete recovery of protoplasts. Protoplasts were sedimented and washed three times in buffer/stabilizer solution to remove traces of lytic enzyme before counting in a haemocytometer.

Chitin synthase assay. Protoplasts were removed from the buffer/stabilizer solution by centrifugation $(800 \mathrm{~g})$ and lysed by resuspension in $200 \mathrm{mM}-\mathrm{Tris} / \mathrm{HCl}$ buffer $\mathrm{pH} 7 \cdot 5$. Complete breakage was ensured by further treatment in a glass homogenizer. The suspension was centrifuged at $200000 \mathrm{~g}$ for $60 \mathrm{~min}$ (SW41 rotor at $35000 \mathrm{rev} . \mathrm{min}^{-1}$ ) using a Beckman L2 65B ultracentrifuge. The pellet was resuspended in $200 \mathrm{~mm}$ Tris/ $\mathrm{HCl}$ buffer $\mathrm{pH} 7.5$ in a glass homogenizer and stored overnight at $-20^{\circ} \mathrm{C}$ before assay. Chitin synthase assays and trypsin digestion of the preparation were carried out by the methods of Ryder \& Peberdy (1977).

Protein determination. Protein was assayed by the method of Lowry et al. (1951) using bovine serum albumin (Sigma) as standard. Protein was previously extracted from whole mycelium by incubation with $1 \mathrm{M}-\mathrm{NaOH}$ for $15 \mathrm{~h}$ at $30^{\circ} \mathrm{C}$. Protoplasts were washed with $0.1 \mathrm{M}$-phosphate buffer pH 5.8 plus $0.4 \mathrm{M}-\mathrm{NH}_{4} \mathrm{Cl}$ as stabilizer to remove residual $\mathrm{KCl}$ which interferes with the protein assay (Vallejo \& Lugunas, 1970). Protein in samples prepared for chitin synthase assay was determined by the standard method and corrected for interference by Tris buffer (Rej \& Richards, 1974).

Dry weight determination. Portions of digestion mixtures were filtered on to weighed glass-fibre discs (Whatman GF/A, 2.4 cm), thoroughly washed with distilled water, and dried to constant weight $(24 \mathrm{~h}$ at $95^{\circ} \mathrm{C}$ ). Quadruple determinations were made in each case. Mycelial mats were dried to constant weight in tared glass containers after thorough washing with distilled water.

\section{RESULTS}

Protoplast release. Examination of digestion mixtures during incubation showed that the pattern of protoplast release differed with the stabilizer used (Fig. 1). In both $\mathrm{KCl}$ and $\mathrm{MgSO}_{4}$ few protoplasts were released early in digestion but maximum yields were similar and were reached after $3 \mathrm{~h}$. In $\mathrm{KCl}$ mixtures there was a steady rise in the number of protoplasts released whereas in $\mathrm{MgSO}_{4}$ mixtures there was a shorter period of more rapid release. After $3 \mathrm{~h}$ digestion the residual mycelium was more fragmented in $\mathrm{MgSO}_{4}$ than in $\mathrm{KCl}$ mixtures. 


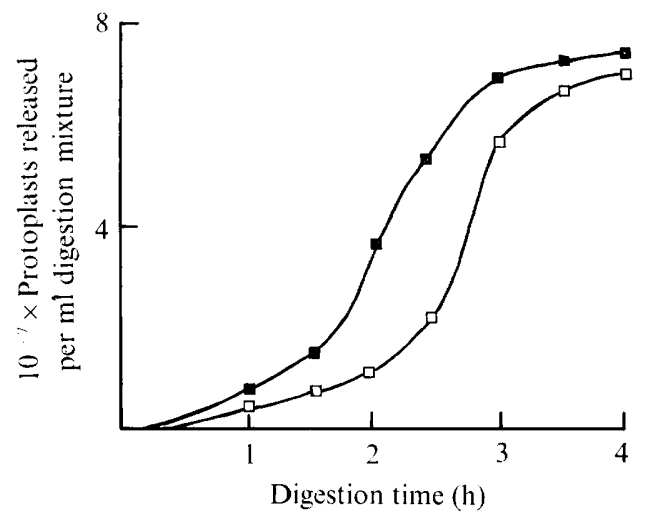

Fig. 1. Pattern of protoplast release in different osmotic stabilizers: $\mathbf{\square}, 0.6 \mathrm{M}-\mathrm{KCl} ; \square, 0.6 \mathrm{M}-\mathrm{MgSO}_{4}$.

Table 1. Diameter of protoplasts released after 1, 2 and $3 h$ digestion in mixtures containing $\mathrm{KCl}$ or $\mathrm{MgSO}_{4}$ as stabilizer

All measurements were made from phofographs of protoplasts in digestion mixtures.

\begin{tabular}{|c|c|c|c|}
\hline \multirow[b]{2}{*}{ Stabilizer } & \multirow{2}{*}{$\begin{array}{l}\text { Digestion } \\
\text { period } \\
\text { (h) }\end{array}$} & \multicolumn{2}{|c|}{ Protoplast diameter $(\mu \mathrm{m})$} \\
\hline & & Mean \pm s.D. & Range \\
\hline $\mathrm{KCl}$ & $\begin{array}{l}1 \\
2 \\
3\end{array}$ & $\begin{array}{l}3.09 \pm 0.85 \\
3.7 \pm 1 \cdot 19 \\
4.08 \pm 1.23\end{array}$ & $\begin{array}{l}1 \cdot 50 \rightarrow 5 \cdot 25 \\
1 \cdot 75 \rightarrow 7 \cdot 00 \\
2 \cdot 75 \rightarrow 8 \cdot 50\end{array}$ \\
\hline $\mathrm{MgSO}_{4}$ & $\begin{array}{l}1 \\
2 \\
3\end{array}$ & $\begin{array}{l}4.92 \pm 1.09 \\
5.65 \pm 1.37 \\
6.17 \pm 1.64\end{array}$ & $\begin{array}{l}2 \cdot 50 \rightarrow 7 \cdot 25 \\
3 \cdot 50 \rightarrow 9 \cdot 25 \\
4 \cdot 00 \rightarrow 10 \cdot 75\end{array}$ \\
\hline
\end{tabular}

Protoplast morphology. The morphological characteristics of protoplasts released from mycelium varied as digestion proceeded. During the first hour of digestion in a $\mathrm{KCl}$ stabilized system, the protoplasts were small and non-vacuolate. The average size of protoplasts increased during the digestion period (Table 1). Late in digestion some vacuolate protoplasts were formed, usually possessing only one vacuole, but sometimes two smaller ones.

In $\mathrm{MgSO}_{4}$-stabilized systems, early protoplasts were also small and non-vacuolate though larger than those produced in $\mathrm{KCl}$. The average sizes of protoplasts increased more markedly as digestion proceeded and during the later stages large, highly vacuolate protoplasts were seen. Early vacuolate protoplasts had one or more small vacuoles, one being larger than the others where several were present. Late in digestion many large protoplasts were formed with the cytoplasm displaced to one side by a large vacuole.

Protein content of protoplasts. Protoplasts were separated from digestion mixtures as described in Methods. At each harvest the percentage recovery was greater than $80 \%$. Yields of protoplasts counted in the digestion mixtures were similar in $\mathrm{KCl}-$ and $\mathrm{MgSO}_{4^{-}}$ stabilized systems (Fig. 1), as were yields of harvested protoplast fractions washed and resuspended in the appropriate stabilizer. Where protoplasts harvested from $\mathrm{MgSO}_{4}$ mixtures by flotation were required in sedimented form, this was achieved by washing with $0.6 \mathrm{M}-\mathrm{KCl}$ in $0 \cdot 1 \mathrm{M}$-phosphate buffer $\mathrm{pH} 5 \cdot 8$. This washing caused lysis of some vacuolate protoplasts, mainly from the $3 \mathrm{~h}$ fractions. All fractions were washed with $0.4 \mathrm{M}-\mathrm{NH}_{4} \mathrm{Cl}$ in $0.1 \mathrm{M}$-phosphate buffer $\mathrm{pH} 5.8$ before protein assay. The change from $0.6 \mathrm{M}-\mathrm{KCl}$ to $0 \cdot 4 \mathrm{M}-\mathrm{NH}_{4} \mathrm{Cl}$ caused less than a $2 \%$ loss due to lysis.

In both $\mathrm{KCl}$ and $\mathrm{MgSO}_{4}$ digestion mixtures, early protoplasts were richer in protein than those formed later in digestion (Table 2). The amounts of protein released per protoplast 


\section{Table 2. Protein content of protoplasts}

Values quoted are the means of at least three determinations.

\begin{tabular}{|c|c|c|c|c|}
\hline Stabilizer & $\begin{array}{l}\text { Digestion } \\
\text { period } \\
\text { (h) }\end{array}$ & $\begin{array}{c}0^{-7} \times \text { protoplast } \\
\text { yield* } \\
(\text { mg dry } \\
\text { mycelium) })^{-1}\end{array}$ & $\begin{array}{l}\text { Protein [mg }\left(10^{8}\right. \\
\left.\text { protoplasts })^{-1}\right]\end{array}$ & $\begin{array}{c}\text { Fraction of } \\
\text { mycelial protein } \dagger \\
\text { released as } \\
\text { protoplasts }(\%)\end{array}$ \\
\hline $\mathrm{KCl}$ & $\begin{array}{l}1 \\
2 \\
3\end{array}$ & $\begin{array}{l}0.03 \\
0.64 \\
1 \cdot 73\end{array}$ & $\begin{array}{l}460 \\
240 \\
300\end{array}$ & $\begin{array}{r}0 \cdot 34 \\
3 \cdot 59 \\
12 \cdot 22\end{array}$ \\
\hline $\mathrm{MgSO}_{4}$ & $\begin{array}{l}1 \\
2 \\
3\end{array}$ & $\begin{array}{l}0.01 \\
0.35 \\
1.24\end{array}$ & $\begin{array}{l}440 \\
160 \\
400\end{array}$ & $\begin{array}{l}0.31 \\
2.53 \\
9 \cdot 50\end{array}$ \\
\hline
\end{tabular}

Table 3. Chitin synthase activities of protoplasts produced in $\mathrm{KCl}$ - and in $\mathrm{MgSO}_{4}$-stabilized systems

Specific chitin synthase activities are expressed as nmol GlcNAc incorporated $\min ^{-1}(\mathrm{mg} \text { protein })^{-1}$, and total activities as nmol GlcNAc incorporated $\min ^{-1}\left(10^{10} \text { protoplasts }\right)^{-1}$. Values quoted are from one representative experiment and are the means of at least three determinations.

\begin{tabular}{|c|c|c|c|c|c|c|}
\hline \multirow{2}{*}{$\begin{array}{l}\text { Diges- } \\
\text { tion } \\
\text { period } \\
\text { (h) }\end{array}$} & \multirow{2}{*}{$\begin{array}{c}10^{-7} \times \\
\text { protoplast } \\
\text { yield } \\
\text { (mg dry } \\
\text { myce- } \\
\text { lium) })^{-1}\end{array}$} & \multicolumn{2}{|c|}{ Untreated protoplasts } & \multicolumn{2}{|c|}{ Protoplasts digested with trypsin } & \multirow{2}{*}{$\begin{array}{c}\text { Increase in } \\
\text { activity } \\
\text { after } \\
\text { trypsin } \\
\text { digestion } \\
(\%)\end{array}$} \\
\hline & & $\begin{array}{l}\text { Specific } \\
\text { activity }\end{array}$ & $\begin{array}{c}\text { Total } \\
\text { activity }\end{array}$ & $\begin{array}{l}\text { Specific } \\
\text { activity }\end{array}$ & $\begin{array}{c}\text { Total } \\
\text { activity }\end{array}$ & \\
\hline \multicolumn{7}{|c|}{ (a) Protoplasts produced in $\mathrm{KCl}$-stabilized system } \\
\hline $\begin{array}{l}1 \\
2 \\
3\end{array}$ & $\begin{array}{l}0 \cdot 14 \\
4 \cdot 25 \\
7 \cdot 55\end{array}$ & $\begin{array}{l}6.13 \pm 0.18 \\
1 \cdot 73 \pm 0.04 \\
0.69 \pm 0.01\end{array}$ & $\begin{array}{r}237.52 \pm 7 \cdot 24 \\
28 \cdot 4 \pm 0 \cdot 67 \\
17 \cdot 42 \pm 0 \cdot 14\end{array}$ & $\begin{array}{l}4 \cdot 14 \pm 0 \cdot 12 \\
2 \cdot 70 \pm 0.03 \\
1 \cdot 05 \pm 0.01\end{array}$ & $\begin{array}{r}168 \cdot 31 \pm 4 \cdot 10 \\
44 \cdot 39 \pm 0 \cdot 56 \\
26 \cdot 24 \pm 0 \cdot 28\end{array}$ & $\begin{array}{l}5 \overline{56 \cdot 07} \\
66 \cdot 57\end{array}$ \\
\hline & Mean & $1 \cdot 09$ & $23 \cdot 99$ & $1 \cdot 59$ & $35 \cdot 27$ & $45 \cdot 87$ \\
\hline \multicolumn{7}{|c|}{ (b) Protoplasts produced in $\mathrm{MgSO}_{4}$-stabilized system } \\
\hline $\begin{array}{l}1 \\
2 \\
3\end{array}$ & $\begin{array}{l}0 \cdot 42 \\
7 \cdot 28 \\
7 \cdot 45\end{array}$ & $\begin{array}{l}0.70 \pm 0.03 \\
1.05 \pm 0.06 \\
1.70 \pm 0.01\end{array}$ & $\begin{array}{r}33 \cdot 73 \pm 1 \cdot 29 \\
6.55 \pm 0.44 \\
16.98 \pm 0.13\end{array}$ & $\begin{array}{l}0.37 \pm 0.05 \\
1.84 \pm 0.08 \\
1.51 \pm 0.08\end{array}$ & $\begin{array}{l}17 \cdot 65 \pm 2 \cdot 34 \\
27 \cdot 19 \pm 1 \cdot 19 \\
15 \cdot 02 \pm 0 \cdot 84\end{array}$ & $\overline{75 \cdot 2}$ \\
\hline & Mean & 1.26 & $16 \cdot 82$ & 1.68 & 22.44 & $33 \cdot 3$ \\
\hline
\end{tabular}

showed similar trends in both stabilizer systems. After $3 \mathrm{~h}$ digestion in $\mathrm{KCl}, 16 \cdot 2 \%$ of the mycelial protein was recovered in protoplast form; $12.4 \%$ was recovered from $\mathrm{MgSO}_{4}$ mixtures.

Chitin synthase activity. Table 3(a) shows chitin synthase activities in protoplast fractions from a representative experiment using a $\mathrm{KCl}$ buffer/stabilizer system. Using this stabilizer the specific activity was highest in the early protoplasts and fell markedly in the later fractions. Protoplasts comprising this fraction represent $1.2 \%$ of the total yield of protoplasts obtained during the full $3 \mathrm{~h}$ digestion period. Using $\mathrm{MgSO}_{4}$ buffer/stabilizer systems the specific activity of chitin synthase was always higher in the later protoplast fractions (Table $3 b$ ). Mean specific activities in all cases were comparable with values obtained for mycelium (Ryder \& Peberdy, 1977).

Proteolytic activation of chitin synthase. Each preparation was digested with trypsin over a range of times to determine the maximum degree of activation. With $\mathrm{KCl}$ as stabilizer, slight activation of chitin synthase was sometimes detectable in preparations from the early protoplast fractions, but the activation was considerably greater in preparations from later 
protoplast fractions (Table $3 a$ ). Using $\mathrm{MgSO}_{4}$ as stabilizer, the distribution of activatable chitin synthase followed a more random pattern (Table $3 b$ ).

The levels of chitin synthase activity, both before and after trypsin treatment, varied in different experiments with the two stabilizers. For each system, however, the trend was the same, the protoplasts released in the first hour of digestion showing consistently higher chitin synthase activities than those formed later.

\section{DISCUSSION}

The effects associated with the use of $\mathrm{MgSO}_{4}$ as an osmotic stabilizer were first described for Schizophyllum commune (De Vries \& Wessels, 1972). In our observations the same effects were also found, namely extensive fragmentation of the mycelium and a marked vacuolation of the protoplasts. With $\mathrm{KCl}$ the mycelium was broken up more slowly and the resultant protoplasts were similar, both morphologically and in the pattern of liberation, to those obtained with $\mathrm{NH}_{4} \mathrm{Cl}$ (Gibson \& Peberdy, 1972).

Yields of protoplasts were sufficient to allow large-scale experiments on individual protoplast fractions. Fawcett et al. (1973) reported the recovery of up to $3 \%$ of the mycelial protein from Cephalosporium acremonium in protoplast form. Using our system with A. nidulans, 12 to $16 \%$ of the mycelial protein was recovered depending on the stabilizer used. The high protein content and levels of chitin synthase activity found in protoplasts released after $1 \mathrm{~h}$ lytic digestion using $\mathrm{KCl}$ as osmotic stabilizer are consistent with the view that these have arisen from the highly active, growing region of the hypha. With $\mathrm{MgSO}_{4}$, however, there is greater overall disruption of hyphae during the lytic digestion and the resultant release pattern appears to be less sequential.

The mean value for chitin synthase specific activity, both before and after trypsin digestion, of the overall protoplast yield using either $\mathrm{KCl}$ or $\mathrm{MgSO}_{4}$ as stabilizer, was very similar to that of mycelial membrane preparations (Ryder \& Peberdy, 1977), suggesting that the protoplasting procedure did not significantly alter the enzyme activity. Similarly, incubation of mycelium in $\mathrm{MgSO}_{4}$ stabilizer did not affect the pattern of activation of chitin synthase (Ryder, 1977). The level of activation obtained in these experiments was higher than that reported by Archer (1977) in studies of protoplasts of A. fumigatus. This may be the result of differences in procedure; the values reported by Archer (1977) relate to a 5 min trypsin digestion whereas in our experiments the highest level of activation was determined by incubating the enzyme preparation with trypsin for various times.

Whilst active forms of the wall polymer synthesizing enzymes might be expected to be present in the growing apical region, it is clear that the potential for the synthesis of chitin, at least, exists along the entire hypha (Katz \& Rosenberger, 1971). This may imply that chitin synthase is subject to some activation system either involving pre-existing enzyme sites (Sternlicht, Katz \& Rosenberger, 1973) or proteolytic activation of a zymogen form (McMurrough \& Bartnicki-Garcia, 1973; Lopez-Romero \& Ruiz-Herrera, 1976; RuizHerrera \& Bartnicki-Garcia, 1976; Ryder \& Peberdy, 1977). It is significant therefore that the early fractions of protoplasts isolated in $\mathrm{KCl}$ possessed higher specific activities than those of later fractions. In addition these early fractions showed little detectable activation by trypsin, significant activation only being detectable in later fractions. If the deduction that the protoplasts liberated after 2 to $3 \mathrm{~h}$ lytic digestion arise from sub-apical zones of hyphae is correct, then these findings would support a model for the distribution of active and zymogen forms of chitin synthase in apical and sub-apical regions, respectively.

S.I. and N.S.R. wish to thank the S.R.C. for Postgraduate Studentships. J.F.P. also thanks the S.R.C. for a research support grant (B/RG 41176). 


\section{REFERENCES}

ARCHER, D. B. (1977). Chitin biosynthesis in protoplasts and sub-cellular fractions of Aspergillus fumigatus. Biochemical Journal 164, 653-658.

BARTNICKI-GarCia, S. (1973). Fundamental aspects of hyphal morphogenesis. Symposia of the Society for General Microbiology 23, 245-268.

BARTNICKI-Garcia, S. \& LiPPMAN, E. (1966). Liberation of protoplasts from the mycelium of Phytophthora. Journal of General Microbiology 42, 411-416.

CABIB, E. (1975). Molecular aspects of yeast morphogenesis. Annual Review of Microbiology 29, 191-214.

De Vries, O. M. H. \& Wessels, J. G. H. (1972). Release of protoplasts from Schizophyllum commune by a lytic enzyme preparation from Trichoderma viride. Journal of General Microbiology 73, 13-22.

De Vries, O. M. H. \& Wessels, J. G. H. (1975). Chemical analysis of cell wall regeneration and reversion of protoplasts from Schizophyllum commune. Archives of Microbiology 102, 209-218.

Fawcett, P. A., Loder, P. B., Duncan, M. J., Beesley, T. J. \& Abraham, E. P. (1973). Formation and properties of protoplasts from antibioticproducing strains of Penicillium chrysogenum and Cephalosporium acremonilim. Journal of General Microbiology 79, 293-309.

Gibson, R. K. \& Peberdy, J. F. (1972). Fine structure of protoplasts of Aspergillus nidulans. Journal of General Microbiology 72, 529-538.

Grove, S. N. \& Bracker, C. E. (1970). Protoplasmic organization of hyphal tips among fungi: vesicles and spitzenkörper. Journal of Bacteriology 104, 989-1009.

KATZ, D. \& Rosenberger, R. F. (1971). Hyphal wall synthesis in Aspergillus nidulans: effect of protein synthesis inhibition and osmotic stabiliser shock on chitin insertion and morphogenesis. Journal of Bacteriology 108, 184-190.

Lopez-Romero, E. \& Ruiz-HerrerA, J. (1976). Synthesis of chitin by particulate preparations from Aspergillus flavus. Antonie van Leeuwenhoek 42, 261-276.

Lowry, O. H., Rosebrough, N. J., FArr, A. L.
\& Randall, R. J. (1951). Protein measurement with the Folin phenol reagent. Journal of Biological Chemistry 193, 265-275.

McMurrough, I. \& Bartnicki-Garcia, S. (1973). Inhibition and activation of chitin synthesis by Mucor rouxii cell extracts. Archives of Biochemistry and Biophysics 158, 812-816.

Peberdy, J. F. (1976). Isolation and properties of protoplasts from filamentous fungi. In Microbial and Plant Protoplasts, pp. 39-50. Edited by J. F. Peberdy, A. H. Rose, H. J. Rogers and E. C. Cocking. London, New York: Academic Press.

Peberdy, J. F. \& IsAac, S. (1976). An improved procedure for protoplast isolation from Aspergillus nidulans. Microbios Letters 3, 7-9.

REJ, R. \& RiChARDS, A. H. (1974). Interference by tris buffer in the estimation of protein by the Lowry procedure. Analytical Biochemistry, 62 , 240-247.

Ruiz-Herrera, J. \& Bartnicki-Garcia, S. (1976). Proteolytic activation and inactivation of chitin synthetase from Mucor rouxii. Journal of General Microbiology, 97, 241-249.

RYDER, N. S. (1977). Chitin synthase in Aspergillus nidulans. Ph.D. thesis, University of Nottingham.

Ryder, N. S. \& Peberdy, J. F. (1977). Chitin synthase in Aspergillus nidulans: properties and proteolytic activation. Journal of General Microbiology 99, 69-76.

Sternlicht, E., Katz, D. \& Rosenberger, R. F. (1973). Subapical wall synthesis and wall thickening induced by cycloheximide in hyphae of Aspergillus nidulans. Journal of Bacteriology 114, 812-823.

Vallejo, C. G. \& Lugunas, R. (1970). Interference by sulphydryl, disulphide reagents and potassium ions on protein determination by Lowry's method. Analytical Biochemistry 36, 207-212.

Villanueva, J. R. \& Garcia ACHA, I. (1971). Production and use of fungal protoplasts. Methods in Microbiology 4, 665-718.

ZALOKAR, M. (1965). Integration of cellular metabolism. In The Fungi, vol. 1, pp. 377-428. Edited by G. C. Ainsworth and A. S. Sussman. New York, London: Academic Press. 